\title{
Municipal Solid Wastes (MSW) Management in High Population Density Areas of Zaria and Kaduna Metropolis in Kaduna State, Nigeria
}

\section{Ahmed Rakiya ${ }^{1}$ and Onyidoh Henry Eric ${ }^{2}$}

\author{
${ }^{1}$ Federal University of Technology, Minna; ${ }^{2}$ Ahmadu Bello University, Zaria \\ Department of Geography, FUT, Minna, Niger State, Nigeria.
}

Article No.: 013018015

Type: Research

DOI: 10.15580/GJEMPS.2018.2.013018015

Submitted: 03/01/2018

Accepted: 06/02/2018

Published: 28/02/2018

${ }^{\star}$ Corresponding Author

Henry Eric Onyidoh

E-mail: anreaeryck@gmail.com

\section{Keywords:}

MSW, recyclables, management, disposal, metropolis, Zaria, Kaduna
Anthropogenic activities on the environment have resulted in the deterioration of the environment, especially in high population density urban areas. The generation of municipal solid wastes (MSW), along with fossil fuel combustion and deforestation have been linked with ecosystem degradation. The study assessed the MSW disposal practices and its challenges in Zaria and Kaduna Metropolitan areas of Kaduna State. A total of 760 questionnaires were administered randomly to residential, institutional and industrial areas. $85 \%$ questionnaires were returned and subjected to descriptive analysis. Over $70 \%$ of the respondents generated $0-1 \mathrm{~kg}$ of MSW, mainly recyclables (35\%), soiled $(24 \%)$ and organic waste $(21 \%)$, of which a majority use refuse dumps $(64.3 \%)$ and incineration (11.3\%) to dispose MSW. 16.9\% agreed that MSW are recyclables, while $66.4 \%$ view MSW as farm manure. Recycling MSW (37.5\%) was advocated as the best control measures of MSW generation, although, inadequacy of MSW management facilities and equipment are considered to be the major challenge affecting ample MSW management, which can lead to pollution of various natural resources. Thus, it is recommended that public enlightenment on the dangers of indiscriminate MSW disposal should be intensified. 


\section{INTRODUCTION}

Waste is any unwanted and discarded object or material, which could be in the form of plastics, rubber, metals (liquid, gaseous and solid forms), oil and other inorganic and organic matter, which is a by-product from industrial, institutional, agricultural or household activities (Benedine et al., 2011, Bogoro and Babanyara, 2011). Wastes are solid or liquid, degradable or non-degradable, renewable or nonrenewable organic or inorganic matter, which is thrown away due to the many anthropogenic activities of humans (THERRA, 2016). Wastes of any kind constitute a nuisance in the environment when not monitored and could lead to debilitating effects on human health, as well as pose a serious challenge to the government and the resident community (Ojo, 2008). He further states that rapid urbanization, burgeoning population density, and high standard of living are some of the factors which are responsible for the increase of Municipal Solid Wastes (MSW) in Nigerian cities. In Onitsha, Anambra State had an estimated total of 386, 593 metric tons of wastes generated in 2007, while in Osun State over 19,000 metric tons of MSW is generated every month (Oluwemimo, 2007). Similarly, Kano State in 2007 generated MSW of over 377,000 metric tons (Afolabi and Adamu, 2008). With this staggering amounts of wastes generated, one might inquire where these MSW end up.

In most Nigerian cities, roadsides, drainage systems, uncompleted buildings, empty land plots, wetlands, water-bodies, etc. have been known to be dumping sites for household wastes by residents, whose unsanitary behaviour is indulged by the ineffectiveness of waste management agencies run by the government (Ojo, 2008). Some authors attribute the indiscriminate dumping of wastes as a result of the inadequacy of infrastructural facilities for MSW management, such as roads, services for waste collection, disposal and treatment, etc. (Bogoro and Babanyara, 2011; Osibanjo, 2008). The improper management of MSW results in heaps of wastes in landfill sites, with negative consequences on the environment which threatens human health, as they become active sites for the breeding of mosquitoes, flies, rodents, etc. Such areas are bases for land, air and water (surface and ground water) pollution, as well as obstruct drainages and roads, which could lead to floods Sridhar, 2008). Biodiversity could also be lost, including revenues from tourism and aesthetics (Ojo, 2008).

In line with these negative outcomes above, MSW needs to be managed. MSW management is defined as any process which controls the generation, collection, storage, transfer, processing and disposal of MSW in line with best standard procedures (MNES, 2001). It has to be a management process which takes into consideration public health, conservation, economic, aesthetics and other environmental conditions when carrying out its functions, and routinely monitors the impact of man's anthropogenic activities on the environment. MSW generation should be sustainable states Stanley et al. (2012), in order not to exceed the earth's carrying capacity; this is because MSW components have varying degenerative periods as shown in table 1.

Table 1: Types and Degenerative Periods of MSW

\begin{tabular}{l|r}
\hline Type of Waste & Approximate Degeneration Time \\
\hline Organic wastes: Vegetative debris, Leftover Foodstuff etc. & $1-2$ weeks \\
Paper & $10-30$ days \\
Cotton Cloth & $2-5$ months \\
Woollen items & 1 year \\
Wood & $10-15$ years \\
Tin, Aluminium, and other metals cans & $100-500$ years \\
Plastic and Plastic bags & 1 million years \\
Glass bottles & Undetermined \\
\hline
\end{tabular}

For MSW generation to be sustainable, there should be a sustainable MSW management plan, combined with an energy generation programme using biodegradable wastes need to be enforced (Stanley et al., 2012). It is also advised that in order to achieve a sustainable MSW management programme, it is also necessary that MSW are segregated and characterized from the source and at recycling points (THERRA, 2016).

Appraising the sustainability management of MSW in Kaduna State, Nigeria, Batagarawa (2011) reported that strategies used in MSW management were ineffective, as Nwude et al. (2009) also inferred that agencies saddled with the responsibility of MSW management in Kaduna metropolis were inefficient. Using Geographic Information Systems (GIS) to determine the impact of spatial distribution of MSW in Samaru, Zaria, Benedine et al. (2011) noted that, MSW disposal affects public infrastructures (roads, drains etc.) which are difficult for environmental agencies to regulate and combat. Thus, this study aim to assess MSW management practices of residents in Zaria and Kaduna metropolises of Kaduna State, Nigeria. The objectives of this research include, to; 
a.Determine the composition of MSW generated in Zaria and Kaduna metropolises.

b.Determine the MSW management practices implemented in Zaria and Kaduna metropolises.

\section{LITERATURE REVIEW}

MSW are created due to varying human activities, hence MSW composition differs significantly between cities, economies and climate. However, MSW can be broadly classified into organic and inorganic (Wolf, 2004). Organic wastes, according to the World Bank (2010), include wastes from food scraps, yard (leaves, grass, and bush) wastes, wood and process residues - majorly from farms and abattoirs, while inorganic wastes include papers of varying kinds, plastics, glass, metals and others, such as textile, leather, rubber, multi-laminates, electronic wastes (e-wastes), appliances, ash and other inert materials. The MSW compositions are largely predisposed to various factors, such as cultural norms, energy sources, climate, geographical location and level of economic development (World Bank, 2010). With population growth and rapid urbanization, cities tend to get wealthier; this triggers an increase in the consumption of inorganic materials (e.g. plastics, paper and aluminium), while organic material consumption relatively decreases (World Bank, 2010). Specifically, MSW composition in high income countries consists of over 54\% inorganic wastes, while in developing countries, such as Nigeria, organic wastes accounts for over 64\% (Zurbrugg, 2003; Sha'Ato et al., 2006; World Bank, 2010).

Usually, domestic wastes from industrialized economies have a high content of packaging (Zurbrugg, 2003), which are basically made of paper, plastics, glass and metals, thus the MSW generated has a low density. However, in developing countries MSW contain huge amounts of inert substances, such as sand, dust, ash, stones due to process of infrastructural construction and reconstruction (Sha'Ato et al., 2006), as well as high moisture levels because of the high usage of fruit and vegetables. These factors (i.e. variable MSW compositions) make wastes very dense, unsuitable for incineration and most often very difficult to recycle (Zurbrugg, 2003). This is why despite the number of MSW management approaches which have been employed to manage MSW in developing countries the open dump disposal method is still a common practice in most developing countries, Nigeria inclusive (Babayemi and Dauda, 2009).

In some notably cities like Onitsha, residents dispose of MSW into streams, while others simple dispose refuse by roadsides (Agwuwamba et al., 1998). Furthermore, in some parts of Port Harcourt, refuse is generally buried around residential units and places of business, although, some are recklessly incinerated (Igoni et al., 2007). It is further reported that several Nigerians consider it convenient and cheap to incinerate MSW in open places and backyards of residential units, which is detrimental to health (Babayemi and Dauda, 2009), as they reiterated that even in the supposed "designated" dumping sites provided by local authorities, mountains of MSW are irresponsibly set on fire, without recourse to the adverse effect this will have on the local populace and the environment.

Due to MSW deposits, Lagos is prone to floods, as a result of clogged drainage channels (Folorunso and Awosika, 2001). They also raised concern on the health of scavengers in designated disposal sites, who constantly inhale toxic air in these sites, as a result of the burning of obsolete electronic waste. Re-echoing this concern, (Oyelola, 2009) reported several illnesses that are consequences of inhaling the smoke emitted from burning MSW. It is believed that the noxious waste disposal habits of Nigerians are responsible for the setbacks which MSW management in Nigeria suffers from (Sangodoyin, 1993; Imam et al., 2008; Babayemi and Dauda, 2009). Wrong MSW disposal practices, amongst which are inadequate service coverage and operational inefficiencies, limited utilization of recycling activities, inadequate landfill disposal and inadequate management of hazardous and healthcare wastes, employed by most residents in developing countries, makes it difficult for optimum MSW management (Zurbrugg, 2003).

\section{METHODOLOGY}

The study was carried out in Zaria Metropolis and Kaduna Metropolis, in Kaduna State, Nigeria during the months of May - July, 2016. Zaria Metropolis has a land mass of $563 \mathrm{~km}^{2}$ and it is located on latitude $11^{\circ} 08^{\prime} 55 \quad \mathrm{~N}$ and longitude $7^{\circ} 71^{\prime} 99$ " $\mathrm{E}$ with a population total of 698,348 according to the 2006 census, using a $3.05 \%$ growth rate per year (NPC, 2006; NBS, 20102), the 2016 estimated population figure would be 942,645 (NBS, 2012). Kaduna Metropolis has a land mass of $3,080 \mathrm{~km}^{2}$, and it is located on latitude $10^{\circ} 51^{\prime} 05^{\prime \prime} \mathrm{N}$ and longitude $7^{\circ} 41^{\prime} 65^{\prime \prime}$ E, with a 2006 census population figure of 767,306 , however, using a growth rate $3.05 \%$ per year (NPC, 2006; NBS, 20102), a 2016 projected population would be approximately $1,067,283$. In Zaria and Kaduna metropolis areas are known to be densely packed, nucleated settlements, with lots of public and private institutions, industries and large markets; which accounts for the high population and commercial activities in the area (Stanley et al., 2012). Cluster sampling was used to divide the metropolitan area into residential units, commercial centres, institutional locations and industrial layouts. In Zaria, residential districts of Kongo, Sabon-gari, Graceland, Zaria-City and G.R.A were randomly sampled, while commercial areas of Tudun-wada, PZ and Sabon-gari Market were sampled. Industrial sites of Chikaji, Muchia and Dakace which are lined with cottage industries in Zaria metropolis were also sampled, inclusive of institutional centres of Samaru, Kongo and Gaskiya. 


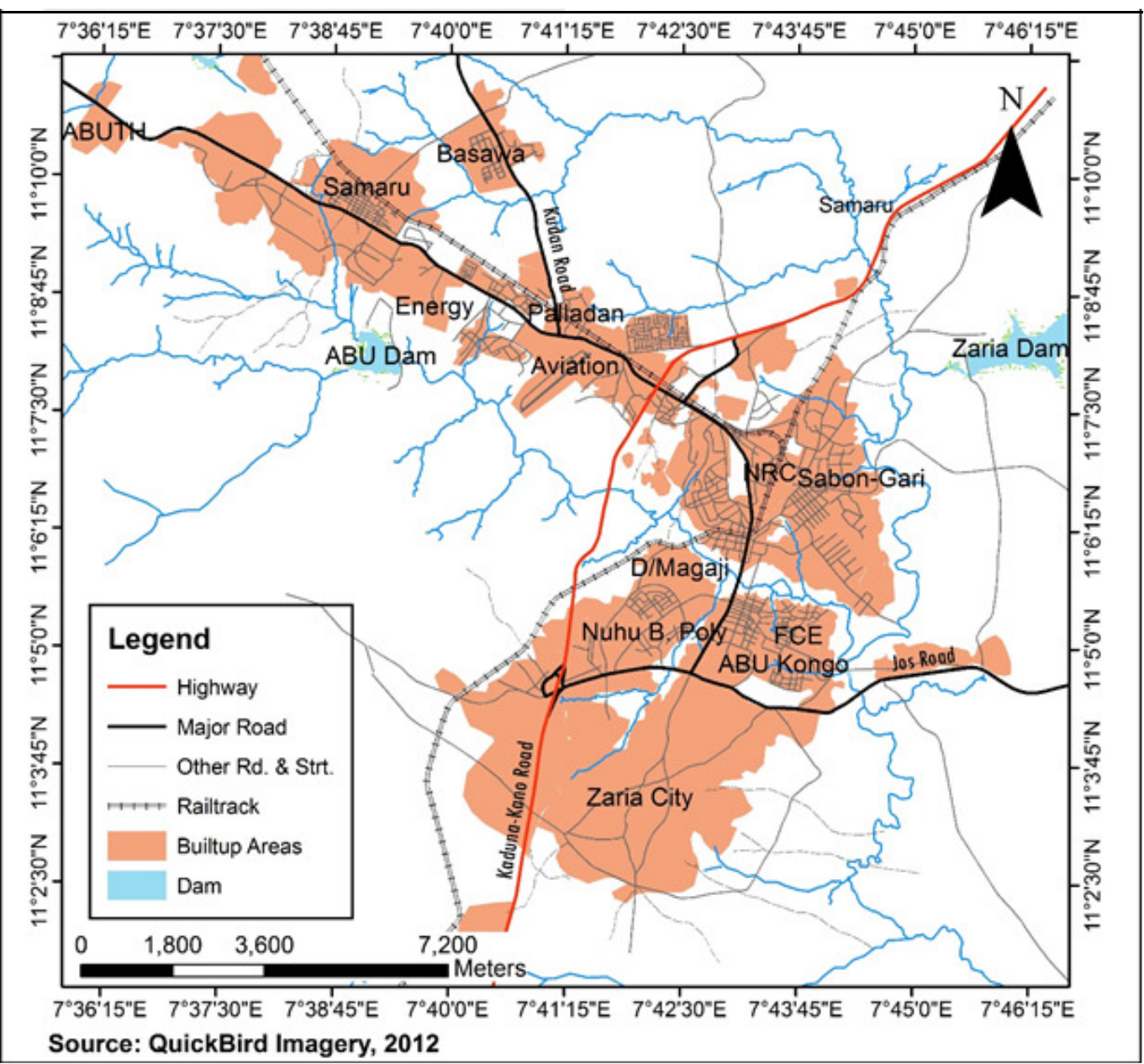

Figure 1: Map of Zaria Metropolis

In Kaduna, residential areas randomly sampled were Unguwar Rimi, Kawo New Extension, Unguwar Dosa, Sabon-Tasha, Narayi and Barnawa, while businesses in commercial areas of Kasuwa, Ahmadu Bello Way,
Kawo, By-Pass, Tudun-Wada were also sampled. Institutional areas of Malali, Tudun-Wada and Unguwar Rimi, and Industrial layouts of Kakuri were randomly sampled. 


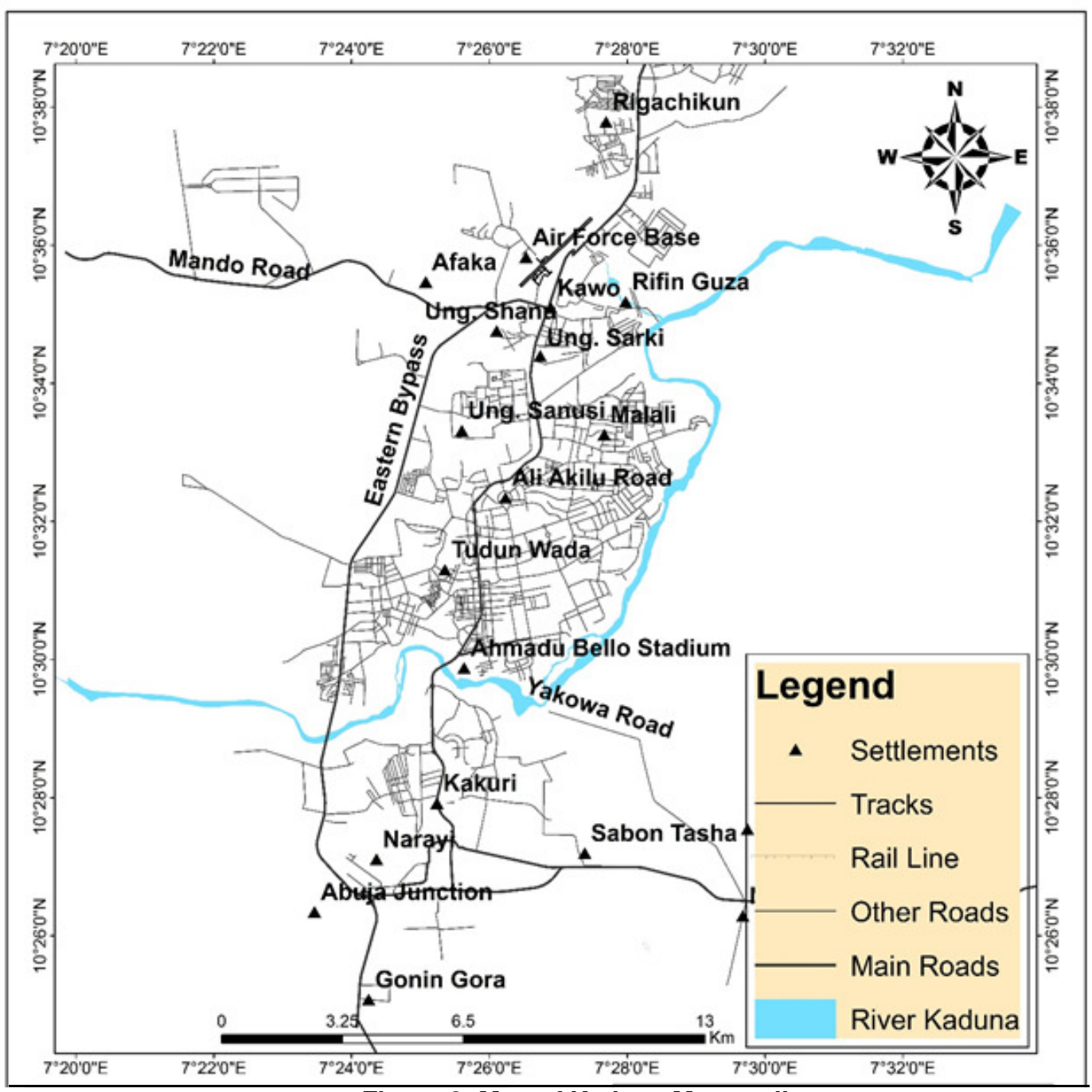

Figure 2: Map of Kaduna Metropolis

\section{Sample Size Determination}

Sample determination was patterned after (Naing et al., 2006) and was considered adequate for the research. The sample size for this study was obtained using the formula:

$n=\frac{Z^{2} p q}{d^{2}}$

(Naing et al., 2006)

Where: $\mathrm{n}=$ the desired sample size

$Z=$ the standard normal deviation, usually set at 1.96

$\mathrm{p}=$ the proportion in the target population having the particular trait (when no estimate $50 \%$ is used; i.e. 0.5 ) $q=1-p$

$\mathrm{d}=$ degree of accuracy desired, usually set at 0.05

Therefore, $\mathrm{n}=(1.96)^{2}(0.5)(0.5) /(0.05)^{2}=384$

Qualitative and quantitative approaches were used in this study, where the administration of questionnaires constituted the data collection tool for this study, as well as face-to-face interviews with eleven (11) staff members of the Kaduna Environmental Protection Agency (KEPA). A total of 760 questionnaires were administered (380 in Zaria Metropolis and another 380 in Kaduna Metropolis) to selected households, commercial, institutional and industrial firms within the study area. 
Table 2: Questionnaire Distribution

\begin{tabular}{|l|llll|llll|ll|}
\hline Units & \multicolumn{5}{|c|}{ Zaria } & \multicolumn{5}{c|}{ Kaduna } \\
& ND & $\%$ & NR & $\%$ R & ND & $\%$ & NR & $\%$ R & Total & Total \% \\
\hline Households & 275 & 72.4 & 245 & 72.9 & 275 & 72.4 & 228 & 73.8 & 473 & 73.3 \\
Commercial & 55 & 14.5 & 49 & 14.6 & 55 & 14.5 & 51 & 16.5 & 100 & 15.5 \\
Centres & 35 & 9.2 & 28 & 8.3 & 35 & 9.2 & 21 & 6.8 & 49 & 7.6 \\
Institutions & 15 & 3.9 & 14 & 4.2 & 15 & 3.9 & 9 & 2.9 & 23 & 3.6 \\
Industries & 380 & 100 & 336 & 88 & 380 & 100 & 309 & 81 & 645 & 85 \\
\hline
\end{tabular}

ND - Number Distributed, NR - Number Returned, \% R - Percentage Returned

A total of $336(88 \%)$ questionnaires were returned, while $44(12 \%)$ were invalid in Zaria, while $309(81 \%)$ was returned in Kaduna metropolis, as $71(19 \%)$ were invalid. A total of $645(85 \%)$ questionnaires were returned and the data obtained were subjected to descriptive statistics, using Microsoft Excel (Windows $8-2011$ ) and presented in form of tables and charts.

\section{RESULTS AND DISCUSSION}

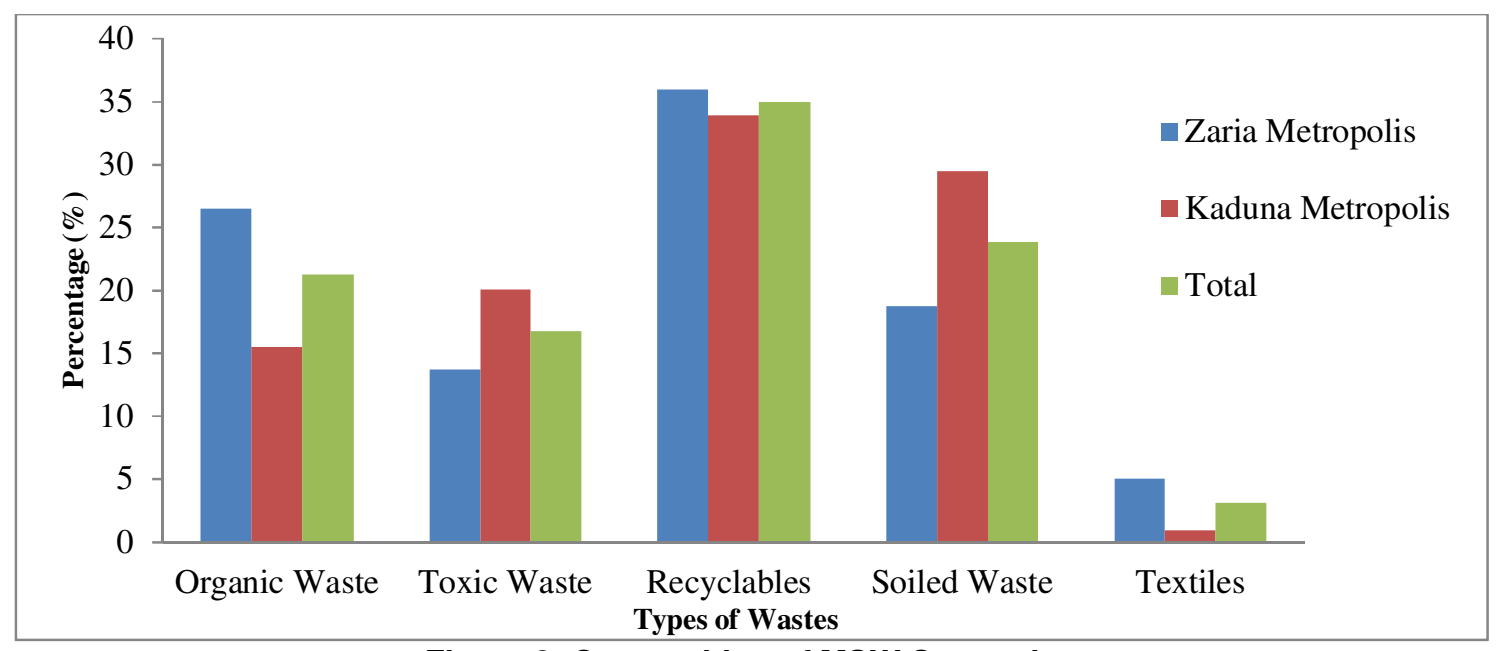

Figure 3: Composition of MSW Generation

The constituents of waste generated by residents, shows that Recyclables (35\%) such as plastics, plastic bags, metals, paper and glass were the most generated in both Zaria Metropolis (36\%) and Kaduna Metropolis (34\%) as shown in Figure 3. Total soiled wastes generated $(24 \%)$ is made up of hospital wastes and anatomical wastes from abattoirs and human faeces, was highest in Kaduna Metropolis (29\%), while that of Zaria Metropolis was (19\%). Kitchen wastes, wood and vegetative debris which make up this class of organic wastes (USEPA, 2016), had a total percentage of $21 \%$, with Zaria Metropolis having $26 \%$, while Kaduna Metropolis was $16 \%$.

Toxic wastes (e.g. discarded chemicals and medicines, batteries and containers of sprays, paints and pesticides) in MSW are a growing phenomenon, as there is little information about its production, use and disposal, especially in low income countries (USEPA, 2016), this is evident in Figure 3, as toxic wastes make up approximately $17 \%$ of the MSW generated in both towns, with the highest in Kaduna
Metropolis (20\%), while Zaria Metropolis was $14 \%$. The total textile wastes generated in both towns was $3 \%$. Textile materials which are majorly composed of woollen materials and other fabrics make up $5 \%$ of the wastes generated in Zaria Metropolis, while that of Kaduna Metropolis was $1 \%$. This difference is of note, as Kaduna metropolis houses two of the most prominent textile industries in northern Nigeria (Arewa and Kaduna Textile Ltd), although they have since been shut down, while the rest six in the State are also in comatose conditions (Leadership Newspaper, 2015), while Zaria have only a single ginnery factory located in Sabon-Gari. Generally, the pattern of wastes generated agrees with (Wolf, 2004; UNEP, 1997; ESCAP, 1999) as they all reported that recyclables and biodegradables are the wastes that are mostly generated in developing countries.

The study also observed that $70.5 \%$ of the total number of respondents generated $0-1 \mathrm{~kg}$ of MSW, as shown in Table 3, while the over $83 \%$ of the respondents temporarily store their generated wastes 
within their house, businesses, institutional or industrial units, with $65.1 \%$ disposing such waste weekly. Only $11 \%$ of respondents segregate wastes before disposal, with Zaria Metropolis having 13.4\% respondents in this category. This result agrees with (Babayemi and Dauda, 2009) who opined that MSW generated daily could be as high 0.71 - $1 \mathrm{~kg}$ in high density urban areas, such as Kaduna, Ibadan, Abuja and Makurdi (Babayemi and Dauda, 2009; Sha'Ato et al., 2006; Imam et al., 2008).

Table 3 further shows that, $64.3 \%$ of the respondents revealed that they dispose their refuse in communal dump sites, this makes such areas susceptible to land, air and water (surface and ground water) pollution, and impede drainages and roads leading to floods (Sridhar, 2008). Incineration (11.3\%) and compost pit (3.1\%) are the least used MSW disposal methods, while (Wolf, 2004) discourages incineration, due to air pollution, he recommends that urban residents should segregate MSW and use compost pits to degenerate organic wastes. In line with this, only $4.2 \%$ of Zaria Metropolis residents keep to this recommendation.

Table 3: MSW Management Practices in Zaria and Kaduna Metropolises

\begin{tabular}{|c|c|c|c|c|c|c|}
\hline Variable & ZMP* & $\%$ & $\mathrm{KMP}^{*}$ & $\%$ & Total & $\%$ \\
\hline \multicolumn{7}{|c|}{$\begin{array}{l}\text { Quantity of Daily Generated } \\
\text { MSW }\end{array}$} \\
\hline $0-1 \mathrm{~kg}$ & 243 & 72.3 & 212 & 68.6 & 455 & 70.5 \\
\hline $2-3 \mathrm{~kg}$ & 78 & 23.2 & 55 & 17.8 & 133 & 20.6 \\
\hline Above 3kg & 15 & 4.5 & 42 & 13.6 & 57 & 8.8 \\
\hline Total & 336 & 100 & 309 & 100 & 645 & 100 \\
\hline \multicolumn{7}{|l|}{ Storage of MSW } \\
\hline Temporarily & 284 & 84.5 & 254 & 82.2 & 538 & 83.4 \\
\hline Permanently (Compost) & 14 & 4.2 & 6 & 1.9 & 20 & 3.1 \\
\hline Immediate Disposal & 38 & 11.3 & 49 & 15.9 & 87 & 13.5 \\
\hline Total & 336 & 100 & 309 & 100 & 645 & 100 \\
\hline \multicolumn{7}{|c|}{ Frequency of MSW Disposal } \\
\hline Daily & 98 & 29.2 & 108 & 35.0 & 206 & 31.9 \\
\hline Weekly & 232 & 69.0 & 188 & 60.8 & 420 & 65.1 \\
\hline Monthly & 6 & 1.8 & 13 & 4.2 & 19 & 2.9 \\
\hline Total & 336 & 100 & 309 & 100 & 645 & 100 \\
\hline \multicolumn{7}{|l|}{ Segregation of MSW } \\
\hline Always & 45 & 13.4 & 26 & 8.4 & 71 & 11.0 \\
\hline Sometimes & 18 & 5.4 & 37 & 12.0 & 55 & 8.5 \\
\hline Never & 273 & 81.3 & 246 & 79.6 & 519 & 80.5 \\
\hline Total & 336 & 100 & 309 & 100 & 645 & 100 \\
\hline \multicolumn{7}{|c|}{ Method of Disposal of MSW } \\
\hline Refuse Dumps & 217 & 64.6 & 198 & 64.1 & 415 & 64.3 \\
\hline Incineration & 40 & 11.9 & 33 & 10.7 & 73 & 11.3 \\
\hline Garbage Company & 65 & 19.3 & 72 & 23.3 & 137 & 21.2 \\
\hline Others (Compost Pit) & 14 & 4.2 & 6 & 1.9 & 20 & 3.1 \\
\hline Total & 336 & 100 & 309 & 100 & 645 & 100 \\
\hline \multicolumn{7}{|c|}{$\begin{array}{l}\text { Monthly Cost of Disposing } \\
\text { MSW }\end{array}$} \\
\hline NO & 271 & 80.7 & 237 & 76.7 & 508 & 78.8 \\
\hline $\mathrm{N} 500-\mathrm{N} 1,500$ & 43 & 12.8 & 55 & 17.8 & 98 & 15.2 \\
\hline $\mathrm{N} 1,500-\mathrm{N} 2,500$ & 15 & 4.5 & 6 & 1.9 & 21 & 3.3 \\
\hline Above N2,500 & 7 & 2.1 & 11 & 3.6 & 18 & 2.8 \\
\hline Total & 336 & 100 & 309 & 100 & 645 & 100 \\
\hline
\end{tabular}

$23.3 \%$ of residents pay sanitary companies to dispose their wastes in Kaduna Metropolis while 19.3\% do same in Zaria Metropolis. Only $2.8 \%$ of the residents pay over $\mathrm{N2,500}$ to garbage companies to dispose their wastes, while $3.3 \%$ pay between $\mathrm{N} 1,500$ to
$\mathrm{N} 2,500$ and $15.2 \%$ pay between $\mathrm{N} 500$ to $\mathrm{N} 1,500$. Majority of the residents $(78.8 \%)$ do not pay for refuse disposal, which suggests a high degree of wastes not being handled properly, with Zaria Metropolis (80.7\%) having the highest frequency in this group. 


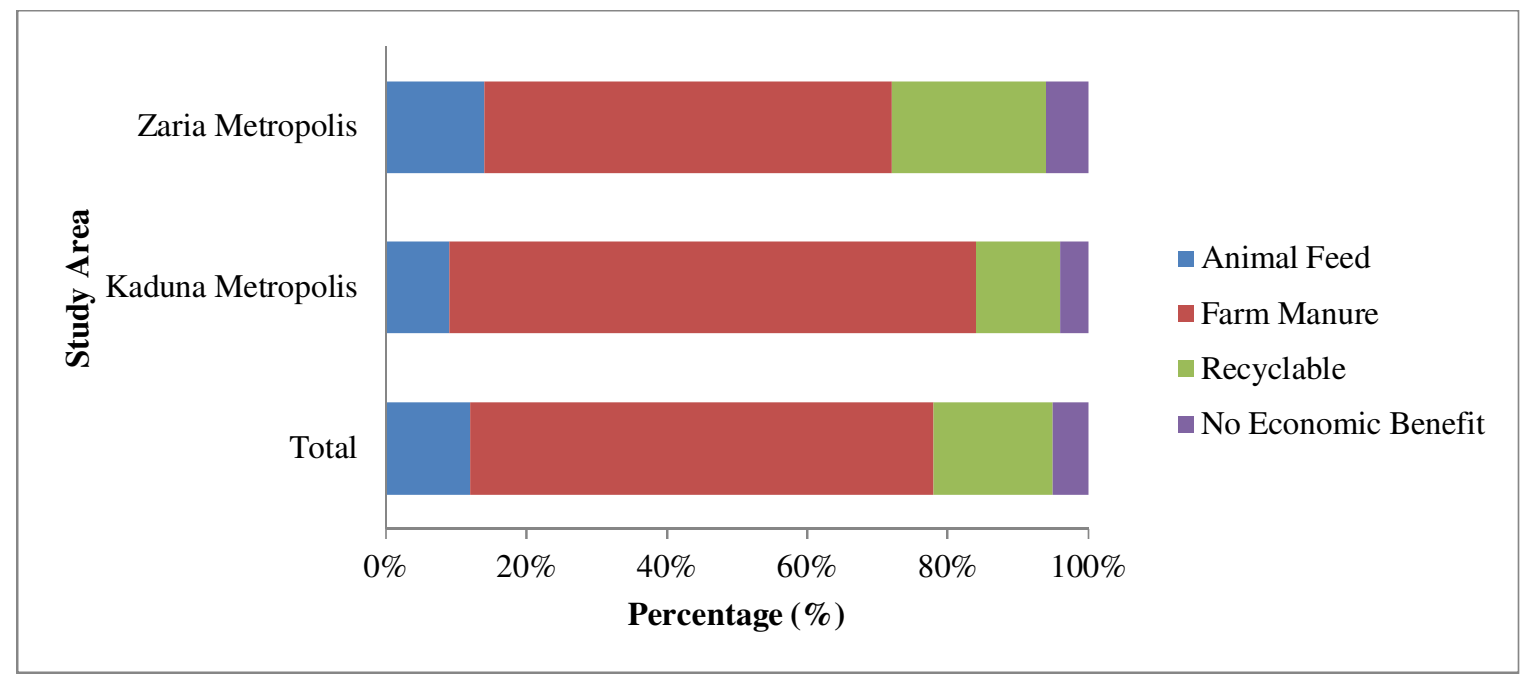

Figure 4: Economic Perception of MSW to Respondents

Figure 4 shows that $75.1 \%$ and $58.3 \%$ of residents in Kaduna Metropolis and Zaria Metropolis, respectively, identified that the economic value of MSW is to produce farm manure. This agrees with Pasquini and Alexander, 2004), as they noted that MSW is used for soil enrichment to boost agriculture in Jos. Furthermore, $21.7 \%$ and $11.7 \%$ for Zaria Metropolis and Kaduna Metropolis, respectively remarked that majority of MSW are being recycled. Approximately
$11.9 \%$ responded that MSW serve as animal feed while only $4.8 \%$ reports that MSW have no economic benefits.

When asked the best strategy to manage the rate which MSW is produced, $37.4 \%$ of the respondents favoured the reduction of items that generate wastes, with Zaria Metropolis (29.2\%) and Kaduna Metropolis (46.3\%), responding affirmatively, as shown in Figure 5.

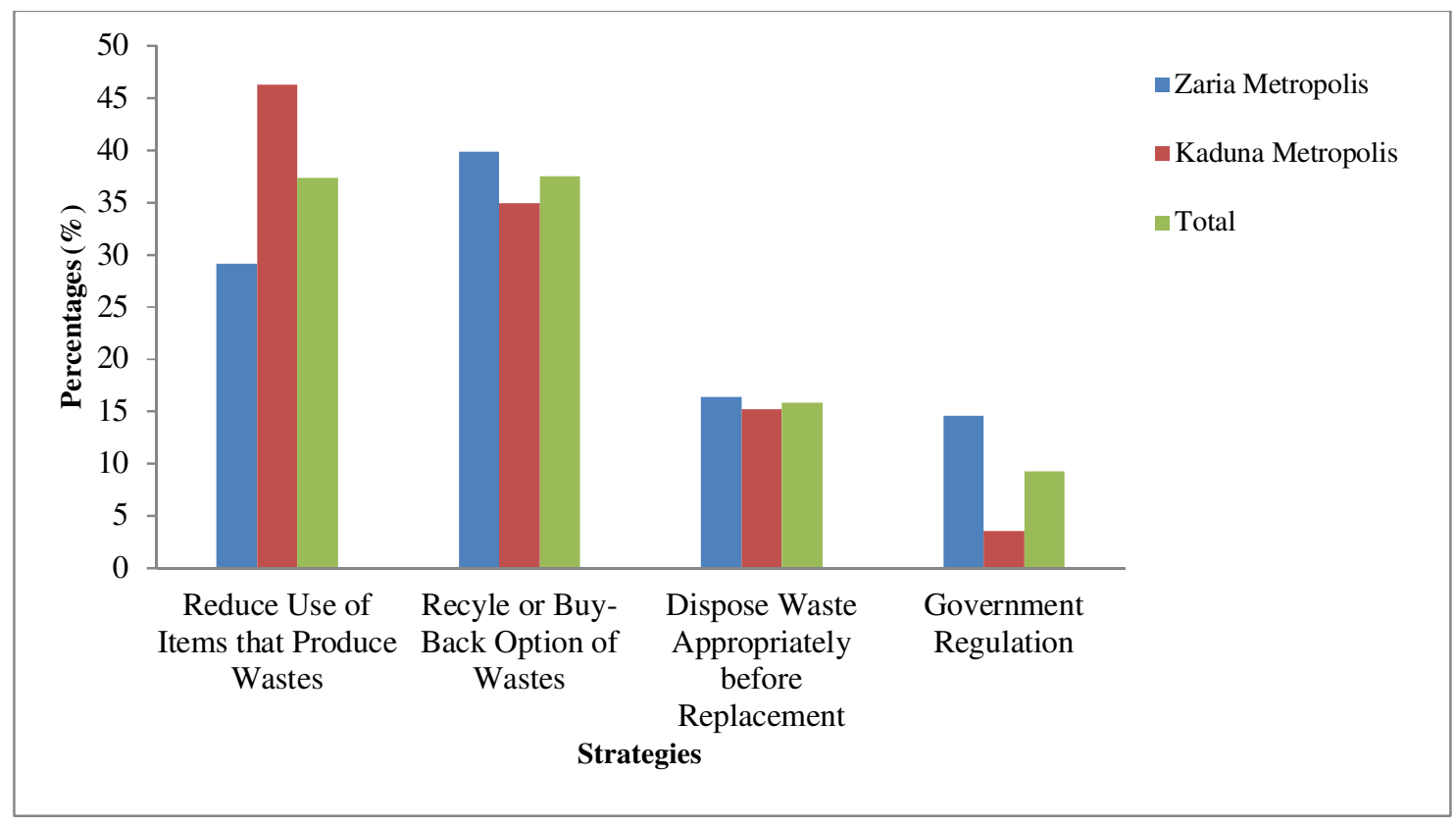

Figure 5. MSW Management Strategies

$37.5 \%$ of the total respondents $39.9 \%$ and $35 \%$ for Zaria Metropolis and Kaduna Metropolis, respectively) revealed that recycling used products or a buy-back option by the product's manufacturers is the best strategy to manage MSW generated by residents, while $15.8 \%$ stated that wastes should be disposed properly before replacing them with another. A further
9.3\% (14.6\% and 36\% for Zaria Metropolis and Kaduna Metropolis, respectively) reported that government regulation to manage waste generation is the best strategy to minimise MSW generation, as shown in Figure 5. This result is in disparity with that of Ojo (2008) and Stanley et al. (2012), who stated that the government should be responsible for the 
regulating the rate at which MSW is generated by the public.

As earlier stated, KEPA is saddled with the duty of handling waste in Zaria and Kaduna towns. It was noted that such agencies are responsible for identifying, constructing and maintaining MSW facilities, as well as sanctioning defaulters of environmental laws as enshrined in the Federal
Environmental Protection Act (FEPA, 1991; Stanley et al., 2012). However, Figure 6 shows results of interviews with staff of the agency, where only $72.7 \%$ agreed that the agency is responsible for the identification of dumpsites, of which $27.3 \%$ inferred that it is not the agency's duty to identify all dumpsites within towns.

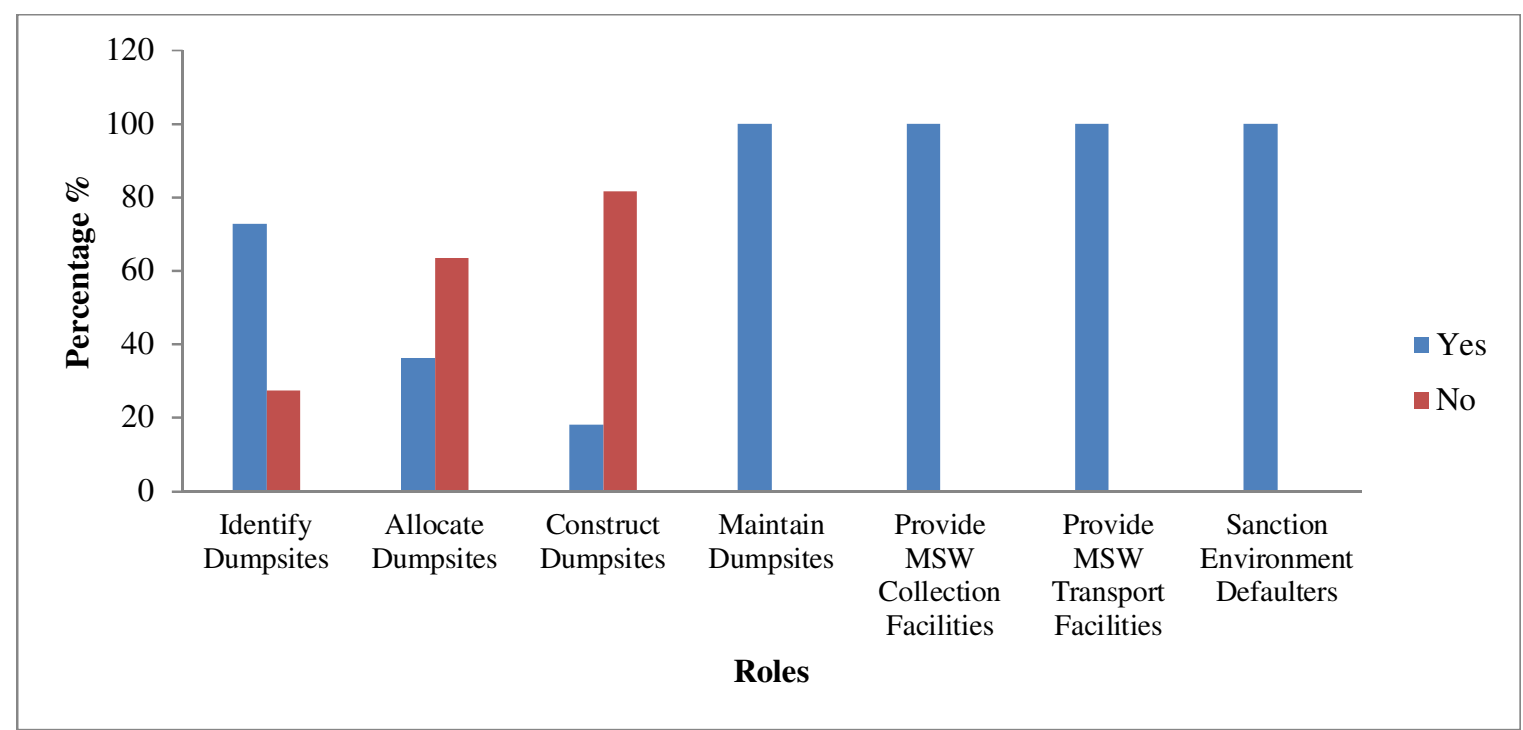

Figure 6: Role of Government Agency in MSW Management

$100 \%$ revealed that the agency is responsible for maintaining dumpsites, providing MSW collection and transport facilities and fining defaulters of environmental laws. Furthermore, 63.6\% revealed that it is not the agency but the State Ministry of Land and Urban Planning that is responsible for earmarking dumpsites or areas for landfills within the State, although, with consultation with the agency. In constructing dumpsites, only $18.2 \%$ affirmed that this is a function of the agency, with $81.8 \%$ in dissent, further stating that the agency only serve as consultants, while the State Ministry of Environment awards the contract for MSW facilities construction. This view is contrary to Stanley et al. (2012) and
Dauda and Osita (2003) who both stated that environmental agencies are responsible for constructing MSW facilities.

On the challenges faced by the agency, $45.5 \%$ and $36.4 \%$ strongly agreed and agreed, respectively, that the inadequacy of MSW management facilities inhibits the ample management of MSW in the towns, the study supports the findings of (Bogoro and Babanyara, 2011), while $18.2 \%$ rated it the least inhibiting factor. $72.7 \%$ strongly agreed that inadequate MSW equipment hinders the agency from performing its functions, while $18.2 \%$ and $9.1 \%$ disagreed and strongly disagreed, respectively. 


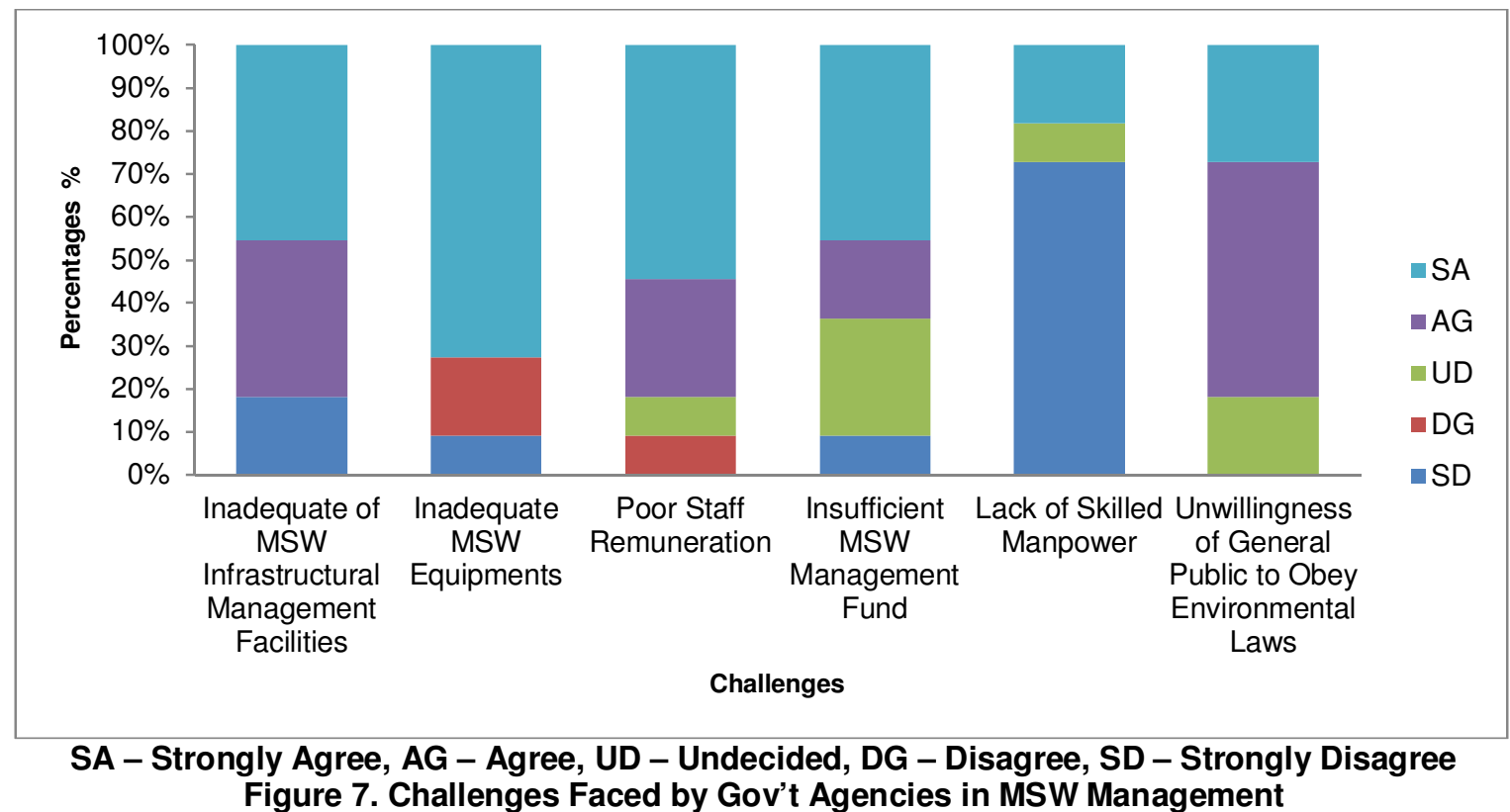

Figure 7 further shows that, $54.6 \%$ and $27.3 \%$ strongly agreed and agreed, respectively, that poor staff remuneration was responsible for the dip in MSW management functions in the towns. The results contrast positively with the (UNEP, 1997) report, which observed that inadequate MSW infrastructural management facilities and equipment, is responsible for dearth of MSW management capability in low income countries. Poor staff welfare was responsible for dysfunctional state of MSW management as corroborated by (Stanley et al., 2012). Inefficient MSW control in the towns was also attributed to insufficient MSW management funding, where $45.5 \%$ strongly agreed that it was a major factor, however, $27.3 \%$ remained undecided in this category. A majority $(72.7 \%)$ strongly disagreed that lack of skilled manpower is a challenge to MSW management in the towns, which is supported by the (USEPA, 2016) report that states that, with the increase of education and training, developing economies have been able to bridge manpower capabilities in managing MSW. However, Babayemi and Dauda (2009) stated that Nigeria and her citizens still has a long way to go in terms of environmental education/awareness, indiscriminate waste disposal and waste management, as $18.2 \%$ strongly agreed that lack of manpower was liable for poor MSW managing mechanism.

Wolf (2004), Ojo (2008), Osibanjo (2008) and Babayemi and Dauda (2009) all agreed with this study (where $54.5 \%$ and $27.7 \%$ agreed and strongly agreed, respectively) that the unwillingness of community residents to obey environmental laws was a major challenge for the agency in carrying out its functions.

\section{CONCLUSION}

The study shows that the two towns generate substantial MSW, which are mostly recyclables, soiled and organic wastes. These MSW are not properly segregated and disposed-off, as refuse dumps and incineration are the two prominent ways by which residents manage their wastes, which is unhealthy for the environment as they cause pollution of air, land and water (surface and groundwater), as well as the clogging of drainage systems, reduce the aesthetic quality of the environment and obstruct vehicular traffic. It is recommended therefore that there's a need for more public enlightenment on the dangers of indiscriminate waste disposal, and encourage residents to obey environmental laws, and advising them to use disposal and collection facilities and services provided by government agencies to minimize MSW, for it is relatively cheap as result indicates. However, adequate MSW facilities and equipment, and appropriate MSW funds both for management and staff welfare of environmental agencies need to be provided, for apt management of MSW.

\section{CONFLICT OF INTEREST}

The authors declare that there is no conflict of interests regarding this paper publication.

\section{REFERENCES}

Afolabi AO and Adamu DJ (2008). Pollution and Waste Management: Challenges Towards Achieving the MDG 7 by 2015. Proceedings of the First National Environment Summit: "Greening the Environment for Sustainable Development." Federal Ministry of Environment, Housing and Urban Development. Transcorp Hilton, Abuja, $20^{\text {th }}-21^{\text {st }}$ April, 2008. pp. 200-209.

Agwuwamba JC, Ukpai OK and Onyebuenyi IC (1998). Solid Waste Management in Onitsha, Nigeria, Waste Mgt Res 16 (1): 23-31.

Babayemi JO and Dauda KT (2009). Evaluation of Solid Waste Generation, Categories and Disposal Options in Developing Countries: A Case Study of Nigeria, J Appl Sci Env Mgt 13(3):83-88. 
Batagarawa RL (2011). Sustainability Appraisal of Waste Management in Nigeria: Development and Evaluation of an Index Based Tool. Unpublished Ph.D. Dissertation, Department of Civil Engineering, University of Portsmouth, UK.

Benedine A, Robert TA, Abbas II. The Impact of Spatial Distribution of Solid Waste Dumps on Infrastructure in Samaru, Zaria, Kaduna State, Nigeria, Using Geographic Information Systems (GIS). Res J Info Tech, 3(3): 113-117.

Bogoro AG and Babanyara YY (2011). Evacuation of Solid Waste in Residential Areas of Bauchi Metropolis, Nigeria. J. Env Sci Res Mgt., 3(1):79 92.

Dauda M and Osita OO (2003). Solid waste management and re-use in Maiduguri, Nigeria. Towards the Millenium Development Goals. 29 ${ }^{\text {th }}$ WEDC International Conference, Abuja, Nigeria, 2003. pp. 20-23.

ESCAP (1999). Economic and Social Survey of Asia and the Pacific: Road Development and Environment - Methodologies for Minimizing Environmental Damages (ST/ESCAP/2027), United Nations Environmental Programme Regional Office for Asia and the Pacific.

FEPA (1991). Federal Environmental Protection Agency. Guidelines and Standards for Environmental Pollution Control in Nigeria, Abuja, Federal Republic of Nigeria.

Folorunso R and Awosika L (2001). Flood mitigation in Lagos Nigeria through the wise management of solid waste: the case of Ikoyi and Victoria Islands. Managing Conflicts Over Resources and Values. Workshop on 'Wise practices for coastal conflict prevention and resolution', Maputo, Mozambique, 19-23 November 2001.

Igoni $\mathrm{AH}$, Ayotamuno MJ, Ogaji SOT and Probert SD (2007). Municipal Solid Waste in Port Harcourt, Nigeria, App Ener, Elsevier 84(6):664-670.

Imam A, Mohammed B, Wilson DC and Cheeseman CR (2008). Solid waste management in Abuja, Nigeria, Waste Mgt 28(2):468-472.

Leadership Newspaper (2015). The Pathetic Story of North's Textiles Industries. Oct. 17, 2015. pp. 28

MNES (2001). Ministry of Non-Conventional Energy Sources - Annual Report 2000 - 2001, Government of India. http://public.wsu.edu/susdev/WCED87.html.

Naing L, Winn T and Rusli BN (2006). Medical Statistics, Arch of Orofacial Sci, 1: 9-14.

NBS (2012). National Bureau of Statistics Annual Abstract of Statistics, 2012, Abuja, Federal Republic of Nigeria, Nigeria.

NPC (2006). National Population Commission Nigerian Demographic and Health Survey 2006, Calverton, Maryland.

Nwude MO, Igboro SB, Umar I and Okuofo CA (2009). Evaluation of Solid Waste Management in Kaduna Metropolis, Nigerian J. of Env't. Geog. http://www.abu.edu.ng/publications/2011-02-03153941_3066.doc

Ojo O (2008). State of the Environment in Nigeria. Proceedings of the First National Environment Summit: "Greening the Environment for
Sustainable Development." Federal Ministry of Environment, Housing and Urban Development. Transcorp Hilton, Abuja, $20^{\text {th }}-21^{\text {st }}$ April, 2008. pp. 60-61.

Oluwemimo O (2007). Social systems, institutions and structures: urbanization, poverty and changing quality of life. Paper presented at the training session of the foundation for environmental development and education in Nigeria, Thursday, February 22, 2007. pp. 45-49.

Osibanjo $O$ (2008). Pollution and Waste: Issue and Management Strategies. Proceedings of the First National Environment Summit: "Greening the Environment for Sustainable Development." Federal Ministry of Environment, Housing and Urban Development. Transcorp Hilton, Abuja, $20^{\text {th }}$ $-21^{\text {st }}$ April, 2008. pp. 87-95.

Oyelola OT, Babatunde AI, Odunlade AK (2009). Health implications of solid waste disposal: case study of Olusosun dumpsite, Lagos, Nigeria, Intl J Pure App Sci 3(2):67-78.

Pasquini MW and Alexander MJ (2004). Chemical properties of urban waste ash produced by open burning on the Jos plateau: implications for agriculture, 2004. Sci Total Envt 319(1-3): 225240.

Sangodoyin AY (1993). Domestic waste disposal in southwest Nigeria, Env Mgt Hth 4(3): 20-23.

Sha'Ato R, Aboho SY, Oketunde FO, Eneji IS, Unazi G, and Agwa S (2006). Survey of solid waste generation and composition in a rapidly growing urban area in central Nigeria, Waste Mgt 27(3):352-358.

Sridhar MKC (2008). Environmental Health and Sanitation. Proceedings of the First National Environment Summit: "Greening the Environment for Sustainable Development." Federal Ministry of Environment, Housing and Urban Development. Transcorp Hilton, Abuja, $20^{\text {th }}-21^{\text {st }}$ April, 2008. pp. 264.

Stanley AM, Andrew SS, Dania AA and Sani IF (2012). An Assessment of Household Solid Waste Disposal Practices in Sabon-Gari, Zaria, ATBU J.Env Tech, 5(1): 48-60.

THERRA (2016). Thermal Energy for Renewables Proposal for the Definition and Calculation Principle of Renewable Heat. http://www.therra.info/pdf/Definition\&Methods/Prop osalDefinitionRESHeat9.pdf. pp. 120-149.

UNEP (1997). United Nations Environmental Programme. Environmental Impact Assessment: Basic Procedures for Developing Countries, Bangkok, United Nations Environmental Programme Regional Office for Asia and the Pacific.

USEPA (2016). United States Environmental Protection Agency. 2016 Municipal Solid Waste New Source Performance Standards (NSPS) and Emission Guidelines (EG) Data Files, https://www.epa.gov/stationary-sources-airpollution/2016-municipal-solid-waste-new-sourceperformance-standards-nsps. 
Wolf, S (2004). Municipal Solid Waste Management in Developing Countries: Nigeria; A Case Study. NTRES: 314-319.

World Bank (2010). What a Waste: A Global Review of Solid Waste Management. Urban Development Series-Knowledge Papers, PP. 16-21.
Zurbrugg, C (2003). Solid Waste Management in Developing Countries, Introductory Text on SWM, EAWAG/SANDEC (1); 1-5.

Cite this Article: Ahmed R and Onyidoh HE (2013). Municipal Solid Wastes (MSW) Management in High Population Density
Areas of Zaria and Kaduna Metropolis in Kaduna State, Nigeria. Greener Journal of Environmental Management and Public
Safety, 7(2): 023-034, http://doi.org/10.15580/GJEMPS.2018.2.013018015. 